\title{
Development of a Novel Monoclonal Antibody to B7-H4: CharaCterization AND Biological ACTIVITY
}

\author{
Y. Qian ${ }^{1,2}$, L. Shen ${ }^{1}$, C. Xu1, Z. Wu ${ }^{1}$, N. H. Brockmeyer ${ }^{3}$, P. Altmeyer ${ }^{3}$, N. Wu ${ }^{1}, H . Y^{1}$ \\ ${ }^{1}$ State Key Laboratory for Diagnosis and Treatment of Infectious Diseases, Institute of Infectious Diseases, First Affiliated Hospital, \\ Zhejiang University School of Medicine, Hangzhou, China \\ ${ }^{2}$ Institute of Immunology, Zhejiang University, Hangzhou, China \\ ${ }^{3}$ Clinic for Dermatology, Venerology and Allergology, Ruhr-University, Bochum, Germany
}

\begin{abstract}
Objective: B7-H4, a member of the B7 family of immunoregulatory receptors, may participate in the negative regulation of cell-mediated immunity. Aberrant B7-H4 expression is detected in some tumors and it plays a role in the occurrence and development of tumors. The aim of this study was to elucidate the functional and structural properties of $\mathrm{B} 7-\mathrm{H} 4$.

Methods: We developed a monoclonal antibody ( $\mathrm{mAb}$ ) against the extracellular domain of B7-H4 through immunization of Balb/c mice with 3T3-mB7-H4 cells which expressed extrinsic B7-H4. A stable hybridoma cell line was established. Then, we analysised the characterization of the $\mathrm{mAb}$ through Enzyme linked immunosorbent assay (ELISA), Immunoprecipitation (IP), western blotting, Immunohistochemical (IHC), and tested the biological activity of the $\mathrm{mAb}$.

Results: ELISA, IP, and western blotting analyses indicated that the $\mathrm{mAb}$ specifically recognized $\mathrm{B} 7-\mathrm{H} 4$. In addition, flow cytometry demonstrated that the $\mathrm{mAb}$ exhibits excellent reactivity when applied to leukemic cells. IHC staining revealed that the $\mathrm{mAb}$ stained in a predominantly diffuse plasmalemmal or cytoplasmic pattern when applied to certain tumor tissues. The preliminary results of the mAb's biological activity showed that the mAb could effectively inhibit the function of $\mathrm{B} 7-\mathrm{H} 4$ in the inhibition of $\mathrm{T}$ cell, while promoting the growth of $\mathrm{T}$ cells and the secretion of Interleukin-2 (IL-2), Interleukin-4 (IL-4), Interleukin10 (IL-10) and Interferon- $\gamma$ (IFN- $\gamma$ ).

Conclusion: This mAb will be a valuable tool for the further investigation of $\mathrm{B} 7-\mathrm{H} 4$ function.
\end{abstract}

Key words: B7-H4; monoclonal antibody; immunologic techniques; biological activity

Abbreviations: mAb: monoclonal antibody; ELISA: Enzyme linked immunosorbent assay; IP: Immunoprecipitation; IHC: Immunohistochemical; IL-2: Interleukin-2; IL-4: Interleukin-4; IL-10: Interleukin-10; IFN- $\gamma$ : Interferon- $\gamma$; RT-PCR: reverse transcription polymerase chain reaction; HRP: horseradish peroxidase; FITC: fluorescein isothiocyanate; OD: optical density.

\section{INTRODUCTION}

The B7 family transmits both costimulatory and coinhibitory signals to $\mathrm{T}$ cells, thus controlling $\mathrm{T}$ cell-mediated immune responses and tolerance. B7-H4 (also known as B7S1 and B7x) is a recently discovered member of the B7 family [1-2], and delivers a co-inhibitory signal that down-regulates $\mathrm{T}$ cell activation, thereby preventing $\mathrm{T}$ cell proliferation, cytokine secretion, and the development of cytotoxicity [1,3-4]. In vitro experiments have shown that $\mathrm{B} 7-\mathrm{H} 4$ inhibits $\mathrm{T}$ cell activation by down-regulating IL-2 production and arresting the cell cycles of both CD4+ and CD8+ T cells. In vivo experiments also support the assamption that B7-H4 functions as an inhibitor to T cell-mediated immunity [1, 3-4].

B7-H4 plays an important role in the immune response mediated by tumors. B7-H4 mRNA transcripts are detected extensively in the spleen, lung, thymus, and other normal tissues; however, the protein is not detectable in these tissues [1]. In contrast, an increasing number of studies using human tumor samples have revealed that $\mathrm{B} 7-\mathrm{H} 4$ is overexpressed in various tumors, including breast [5-6], ovarian [5, 7], renal [8], prostate [9], and non-small cell lung cancers [10], and that B7-H4 expression, as assessed using RT-PCR and IHC, is associated with disease progression. In addition, B7-H4 is expressed in tumor-associated suppressive macrophages [11] and the serum level of soluble B7-H4 is elevated in patients with renal cell carcinoma and ovarian cancer [12-13]. Previous studies [5-6, 14] have shown that the high expression of $\mathrm{B} 7-\mathrm{H} 4$ protein in breast cancer decreases the number of tumor-infiltrating lymphocytes and prevents tumor cell apoptosis.

Therefore, the $\mathrm{B} 7-\mathrm{H} 4$ protein is a negative regulator of the antitumor immune response and may play an important role in promoting tumor growth. To elucidate the functional and structural properties of B7H4, several different epitope-specific antisera against B7-H4 have been raised in rabbits or goats. However, there is little $\mathrm{mAb}$ available that can be used for IHC or other analyses. In the present study, we developed a new $\mathrm{mAb}$ against the extracellular domain of $\mathrm{B} 7-\mathrm{H} 4$. This development had great utility for immunoblot- 
ting, indirect immunofluorescence staining, IP, flow cytometry, and IHC staining. And it also had inhibitive biological function to B7-H4. Accordingly, this monoclonal antibody will provide a powerful tool for the further investigation of B7-H4 function.

\section{Materials AND Methods}

Production of Anti-B7-H4 Monoclonal Antibody

Living 3T3-mB7-H4 cells $\left(5 \times 10^{6}\right)$, which were prepared as described previously [15], were used as immunogens to immunize $6 \mathrm{Balb} / \mathrm{c}$ mice (Shanghai Laboratory Animal Center, Chinese Academy of Sciences) one injection biweekly (every 2 weeks) repeated 4 times. The 2 mice with the highest antibody titer as determined by ELISA were boosted intraperitoneally with 3T3-mB7-H4 cells 3 days before cell fusion. Peritoneal macrophages from normal Balb/c mice used as feeder layer cells were prepared 1 day prior to fusion. Spleen cells from immunized animals were fused with Sp2/0 myeloma cells (ATCC, VA, USA) [16]. More than 100 independent hybridomas were obtained from 2 fusions. Pooled culture fluids from individual hybridoma cultures were screened for their reactivity with the lysates of 3T3-mB7-H4 cells using direct ELISA and by IP analysis. Lysates of 3T3 cells (ATCC) not transfected with B7-H4 were used as a control [17]. A positive hybridoma line of $3 \mathrm{E} 8$ was established by limiting dilution. Isotypes of the mAbs produced were identified using a mouse monoclonal isotyping kit (AbD Serotec, NC, USA). Further, the hybridoma cells were injected intraperitoneally into a Balb/c mouse to obtain ascites containing high concentrations of the $\mathrm{mAb}$. The $\mathrm{mAb}$ was purified from mouse ascites using a protein L UltraLink Column (Pierce, IL, USA), and then stored at a concentration of $1.5 \mathrm{mg} / \mathrm{mL}$.

\section{ENZYME LINKED IMMUNOSORBENT ASSAY}

3T3-mB7-H4 or 3T3 cells $\left(1 \times 10^{6}\right)$ were lysed in 200 $\mu \mathrm{L}$ Cell Lysis Buffer (Cell Signaling Technology, MA, USA) for $30 \mathrm{~min}$ at $4{ }^{\circ} \mathrm{C}$. The insoluble material was then removed by centrifugation at $8000 \times \mathrm{g}$ for 10 min. The concentration of protein in the lysate was determined using a BCA protein assay kit (Pierce) with BSA as the standard.

The lysate of 3T3-mB7-H4 cells, diluted to 10 $\mu \mathrm{g} / \mathrm{mL}$ in $0.01 \mathrm{M}$ coating solution concentrate (KPL Company, Maryland, USA), was coated onto highbinding polystyrene plates (Corning Life Sciences, MA, USA) at $100 \mu \mathrm{L}$ per well, and incubated at $4^{\circ} \mathrm{C}$ overnight. The lysate of $3 \mathrm{~T} 3$ cells not transfected with B7-H4 was used as a control. The wells were subsequently washed 5 times with PBS-Tween buffer $(0.05 \%$ Tween 20 in PBS). The coated wells were blocked with $200 \mu \mathrm{L}$ of $3 \% \mathrm{BSA}$ for $2 \mathrm{~h}$ at room temperature and then incubated with $100 \mu \mathrm{L}$ culture supernatant of hybridoma cells or different dilutions of the $\mathrm{mAb}$ against B7-H4. After incubation for $1 \mathrm{~h}$ at room temperature, the wells were thoroughly washed, and then incubated with $100 \mu \mathrm{L}$ horseradish peroxidase-conjugated goat anti-mouse IgM (dilution 1:5000; Santa Cruz, CA, USA) for $1 \mathrm{~h}$ at room temperature. The plates were developed using tetramethylbenzidine substrate solution
(KPL Company) for 10 20 $\mathrm{min}$ at room temperature. Color development was stopped with $2 \mathrm{M} \mathrm{H}_{2} \mathrm{SO}_{4}$ and the absorbance was measured at $450 \mathrm{~nm}$ using a Model 680 microplate reader (Bio-Rad, CA, USA).

\section{Western Blotting Analysis}

Cell lysate preparation and western blotting analysis were performed according to previously described procedures. In brief, cell lysates were denatured for 10 min at $95^{\circ} \mathrm{C}$ with SDS-PAGE sample loading buffer, electrophoresed on 10\% SDS-PAGE gels, and transferred to polyvinylidene difluoride membranes. The membranes were blocked with 5\% nonfat milk in TBST [20 mM Tris-HCl (pH 7.5), $150 \mathrm{mM} \mathrm{NaCl}$, and $0.05 \%(\mathrm{v} / \mathrm{v})$ Tween 20 and incubated with $3 \mathrm{E} 8 \mathrm{mAbs}$ or goat anti-B7-H4 polyclonal antibody (R\&D Systems, MN, USA) for $2 \mathrm{~h}$ at room temperature. After thorough washing, the blots were incubated with HRP conjugated goat anti-mouse IgM antibodies (Santa Cruz) or rabbit anti-goat IgG antibodies (Santa Cruz).The reaction was developed using ECL reagents (Amersham, NJ, USA) and analyzed using a VersaDoc MP5000 imaging system (Bio-Rad).

\section{IP ANALYSIS}

B7-H4 was immunoprecipitated from the 3T3-mB7$\mathrm{H} 4$ or 3T3 cells lysates. Individual samples $(350 \mu \mathrm{g}$ protein/sample) were immunoprecipitated using 3E8 $\mathrm{mAb}(2 \mu \mathrm{g} /$ sample) coupled to protein L-Sepharose beads. The purified recombinant B7-H4 protein [18] immunoprecipitated with normal mouse IgM was used as an antibody control [16]. Western blotting was carried out using goat anti-B7-H4 polyclonal antibody as the primary antibody, followed by rabbit anti-goat IgG antibody coupled with HRP. The reaction was developed as described above.

\section{Flow Cytometry Analysis}

In order to analyze the specificity of antibody, leukemic cells such as U937, THP-1, HL60, and MM1R cells (ATCC) were used in this study. Each of cells (2 $\left.\times 10^{6}\right)$ was incubated with $3 \mathrm{E} 8 \mathrm{mAb}$ or goat anti-B7$\mathrm{H} 4$ polyclonal antibody for $30 \mathrm{~min}$ at $4{ }^{\circ} \mathrm{C}$. The normal mouse IgM was used as an antibody control. Cells were washed and resuspended in a goat anti-mouse IgM coupled with FITC or donkey anti-goat IgG coupled with FITC (Jackson ImmunoResearch Laboratories, PA, USA) for $30 \mathrm{~min}$ at $4{ }^{\circ} \mathrm{C}$. Finally, cells were washed twice and samples were analyzed using a flow cytometer (FACScan, CA, USA).

\section{IMMUNOHISTOCHEMICAL STAINING}

Tissue microarrays were obtained from Chaoying Biotechnology Co., LTD (Shanxi, China) for IHC staining. Tumor samples included those from the breast, uterus, and ovary. Clinical and pathological information for individual cancer samples was provided by the array manufacturers (for details see www.cybrdi.cn). IHC staining was carried out using $3 \mathrm{E} 8 \mathrm{mAb}$ as the primary antibody followed by reagents from the 
EnVision System (DAKO, CA, USA). Normal mouse IgM was used as an antibody control. Staining intensity ( 0 to 3 , least intense to most intense) and the proportion of stained cells ( 0 to 4 , no cells stained to more than $70 \%$ cells stained) were semi-quantitatively determined as previously described [19]. A combined score of $\geq 2$ and $\geq 6$ was considered to indicate positive expression and overexpression, respectively. All slides were scored by 2 observers blinded to the pathology and clinical features.

\section{Spleen Cell Growth Determined by MTS}

Spleen cells from normal Balb/c mouse $\left(2 \times 10^{5}\right.$ cells per well) were seeded in triplicate in a 96-well plate which was coated with anti-mouse CD3 mAb (R\&D Systems). Then, the cells were incubated with the purified recombinant B7-H4 protein [18] (2ug/ml), 3E8 $\mathrm{mAb}(1 \mathrm{ug} / \mathrm{ml}, 2 \mathrm{ug} / \mathrm{ml}$, and $5 \mathrm{ug} / \mathrm{ml})$, or their admixture which was premixed for $30 \mathrm{~min}$. Normal mouse $\operatorname{IgM}(5 \mathrm{ug} / \mathrm{ml})$ was used as an antibody control. After incubating the wells for 72 hours at $37^{\circ} \mathrm{C}$, the wells were added with CellTiter $96^{\circledR} \mathrm{AQ}$ ueous One Solution Cell Proliferation Assay (MTS) (Promega, WI, USA). After incubating the wells for 4 hours at $37^{\circ} \mathrm{C}$, the OD of each well was measured using a Model 680 microplate reader at a wavelength of $490 \mathrm{~nm}$.

\section{Cytokines Determined by ELISA}

While in cytokines secretion assay, spleen cells were treated as above. The Cell culture supernatant was collected respectively after incubating the wells for 48 or 72 hours at $37^{\circ} \mathrm{C}$. The expression of IL-2, IL-4, IL-10 in $48 \mathrm{~h}$ supernatant, and IFN- $\gamma$ in $72 \mathrm{~h}$ supernatant were determined with mouse cytokine ELISA kit (eBioscience, CA, USA), and was denoted by optical density at $450 \mathrm{~nm}$.

\section{STATISTICAL ANALYSIS}

All experiments were performed in triplicate. The data were analyzed using SPSS 11.0 software, and $\mathrm{P}<0.05$ was considered to indicate a significant difference.

\section{RESULTS}

\section{Isotype of the Mouse Monoclonal Antibody} AGAINST B7-H4

The 3E8 hybridomas that reacted selectively with B7$\mathrm{H} 4$ in all assays were further evaluated. The isotype of the 3E $8 \mathrm{mAb}$, determined using a mouse monoclonal isotyping kit (AbD Serotec), was an IgM with a $\kappa$ chain (Fig. 1). Immunofluorescence analysis confirmed that $3 \mathrm{E} 8$ binds to the extracellular sequences of B7-H4. Species cross-reactivity studies showed that $3 \mathrm{E} 8$ was specific to the human and mouse B7-H4 proteins (data not shown).

\section{Characterization of THE 3E8 mAB Specific} TO B7-H4

ELISA analysis revealed that compared with the control, the titer of $3 \mathrm{E} 8$ was high, as B7-H4 was de- tectable at a dilution of $1: 20000$ (Fig. 2). The immunoreactivity of $3 \mathrm{E} 8 \mathrm{mAb}$ with the lysate of 3T3$\mathrm{mB} 7-\mathrm{H} 4$ cells is shown in Figure 3A. Mature B7-H4 is a 50 - to $80-\mathrm{kDa}$ glycosylated molecule with a $28-\mathrm{kDa}$ protein core [5]. The $3 \mathrm{E} 8 \mathrm{mAb}$ specifically recognized protein bands of 28 and $57 \mathrm{kDa}$. The goat anti-B7-H4 polyclonal antibody also reacted with both proteins in the same experiment (Fig. 3B) as controls, and similarly sized proteins were detected. ELISA and western blotting revealed that $3 \mathrm{E} 8$ can specifically recognize recombinant B7-H4 in mammalian cells.

\section{The 3E8 mAв ImmunoprecipitATes B7-H4 From Cell Lysates}

Next we used IP to determine the ability of $3 \mathrm{E} 8 \mathrm{mAb}$ to recognize $\mathrm{B} 7-\mathrm{H} 4$ in its native state. Cell extracts were immunoprecipitated with the $3 \mathrm{E} 8 \mathrm{mAb}$ and analyzed by immunoblotting using a goat anti-B7-H4 polyclonal antibody. B7-H4 was selectively immunoprecipitated from 3T3-mB7-H4 cell lysates that expressed B7-H4 (Fig. 3C). IP of lysates with mouse normal IgM did not result in detection of protein species. No corresponding band was visualized when the $3 \mathrm{E} 8 \mathrm{mAb}$ was used to immunoprecipitate lysates of normal 3T3 cells. Therefore, the $3 \mathrm{E} 8 \mathrm{mAb}$ specifically recognizes native $\mathrm{B} 7-\mathrm{H} 4$.

\section{Flow Cytometry AnAlysis of B7-H4 Expression IN LEUKEMIC CELLS}

We assayed the human lymphoid hematopoietic tumor cell lines U937, THP-1, HL60, and MM1R for expression of B7-H4 using flow cytometry. $3 \mathrm{E} 8 \mathrm{mAb}$ and goat anti-B7-H4 polyclonal antibody (used as a positive control) were used as probes to detect significant increases in fluorescence intensity in comparison to cells incubated with PBS (Fig. 4). The binding efficiencies of U937, THP-1, HL60, and MM1R cells with 3E8 $\mathrm{mAb}$ were $98.4 \%, 88.4 \%, 72.2 \%$, and $12.7 \%$, respectively, whereas those with goat anti-mB7-H4 antibody were $98.9 \%, 91.0 \%, 84.6 \%$, and $30.8 \%$, respectively. No reactivity was detectable in the normal mouse IgM group ( $\leq 0.5 \%)$.

\section{AsSAY OF B7-H4 EXPRESSION BY IMMUNOHISTOCHEMICAL STAINING}

Three types of normal tissue and their corresponding cancerous tissues with case numbers from 22 to 30 in the tissue microarrays were subjected to IHC staining. Scores $\geq 6$ were considered to indicate overexpression. In general, B7-H4 was stained with a diffuse pattern either in the membrane or in the cytoplasm of cells. Table 2 summarizes the results of these studies. Immunoreactive B7-H4 was detected in different types of normal tissue and their corresponding cancer cells with different expression patterns and intensities (Fig. 5). Whereas most tissues expressed B7-H4 to some degree, samples with scores $\leq 2$ were mostly observed in normal tissue with a predominantly apical membranous staining. Overexpression of B7-H4 (scores $\geq 6.0$ ) was found only in tumor tissues. 


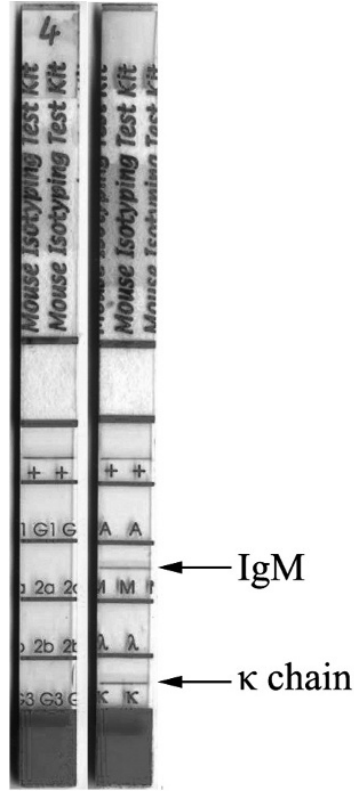

Fig. 1. The isotype of mouse monoclonal antibody against B7H4. - The isotype of the 3E8 $\mathrm{mAb}$, determined using a mouse monoclonal isotyping kit, was an IgM with a $\kappa$ chain.

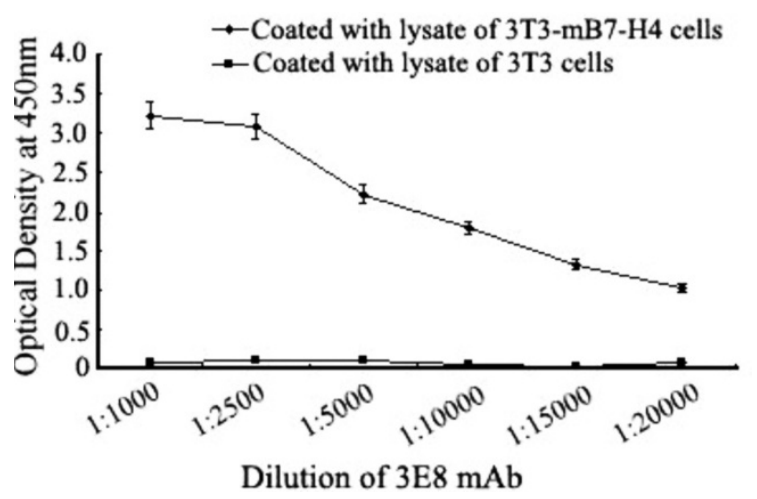

Fig. 2. ELISA analysis of anti-B7-H4 mAb. - The lysate of 3T3-mB7-H4 cells, diluted to $10 \mu \mathrm{g} / \mathrm{mL}$ in $0.01 \mathrm{M}$ coating solution concentrate, was coated onto high-binding polystyrene plates at $100 \mu \mathrm{L}$ per well, and incubated at $4{ }^{\circ} \mathrm{C}$ overnight. The lysate of $3 \mathrm{~T} 3$ cells not transfected with B7-H4 was used as a control. The titer of 3E8 (at an original concentration of 1.5 $\mathrm{mg} / \mathrm{mL}$ ) was determined by ELISA and read at $\mathrm{A}_{450}$.

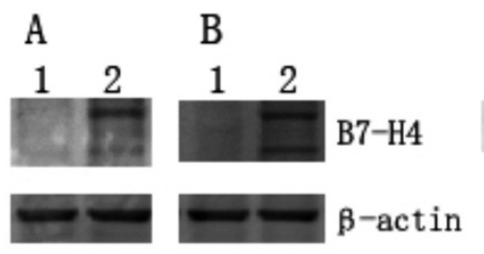

Fig. 3. IP and western blotting analysis with $3 \mathrm{E} 8 \mathrm{mAb}$ - $-\mathrm{A}$ : Western

C

\section{3} blotting was carried out for B7-H4 from lysates of 3T3-mB7-H4 or 3T3 cells using $3 \mathrm{E} 8 \mathrm{mAb}$, followed by goat anti-mouse IgM antibody coupled with HRP. B: Western blotting was carried out for B7-H4 from lysates of $3 \mathrm{~T} 3-\mathrm{mB} 7-\mathrm{H} 4$ or $3 \mathrm{~T} 3$ cells using goat anti-B7-H4 polyclonal antibody, followed by rabbit anti-goat IgG antibody coupled with HRP. There were protein bands of 28 and $57 \mathrm{kDa}$ in $\mathrm{A}$ and $\mathrm{B}$. C: B7-H4 was immunoprecipitated from lysates of $3 \mathrm{~T} 3-\mathrm{mB} 7-\mathrm{H} 4$ or $3 \mathrm{~T} 3$ cells using

3E8 mAb (2 $\mu \mathrm{g} /$ sample). Western blotting was carried out for B7-H4 using goat anti-B7-H4 polyclonal antibody, followed by rabbit anti-goat IgG antibody coupled with HRP. Normal mouse IgM was used as an antibody control. Lane 1: lysate from normal 3T3 cells; Lane 2: lysate from 3T3-mB7-H4 cells; Lane 3: B7-H4 unrelated antibody control.

A
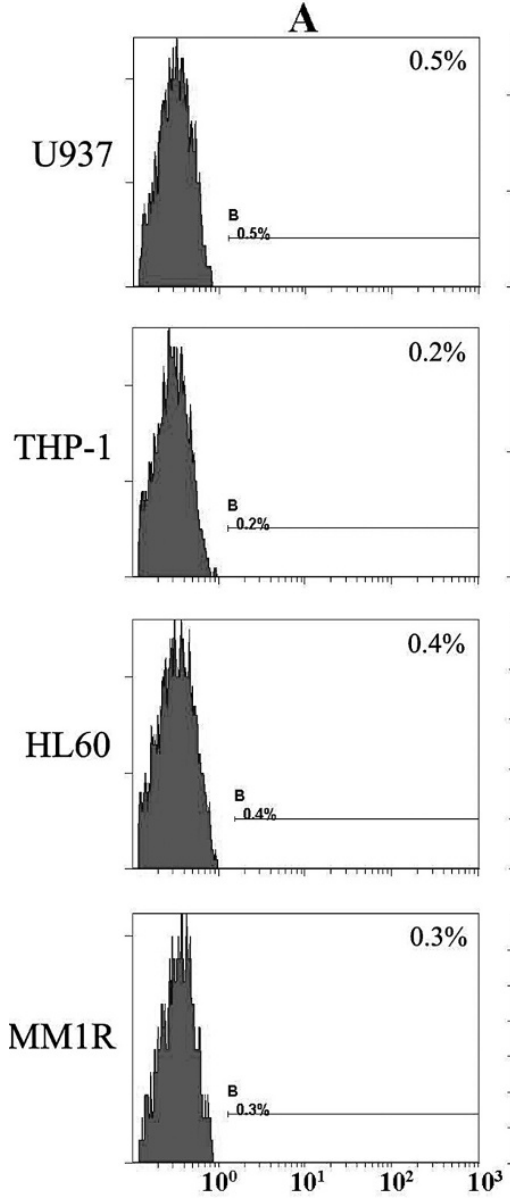

B
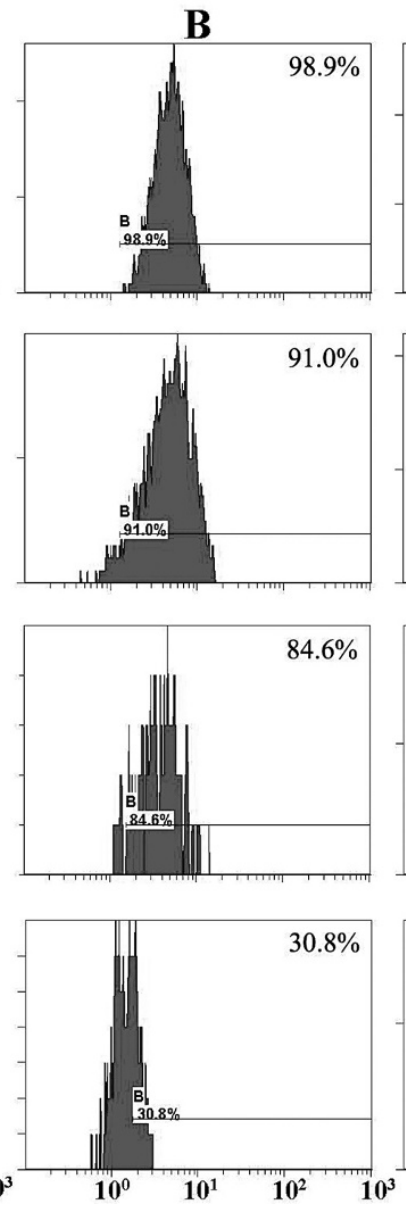
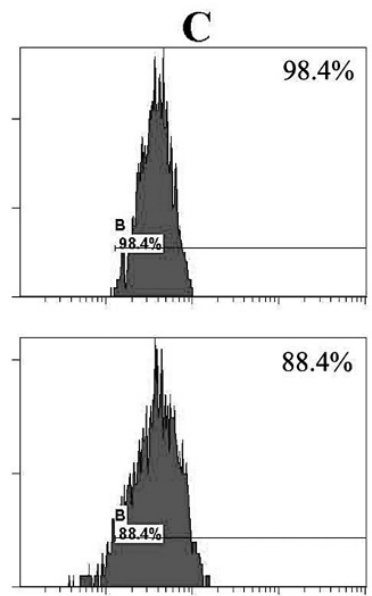

$72.2 \%$
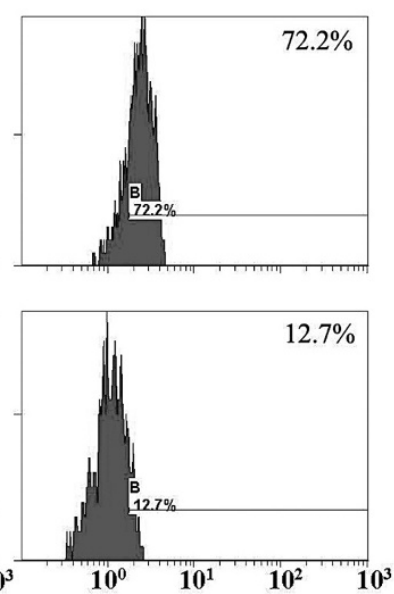

Fig. 4. Flow cytometry analysis with $3 \mathrm{E} 8 \mathrm{mAb}$. U937, THP-1, HL60, and MM1R cells $\left(2 \times 10^{6}\right.$ cells per sample in PBS) were incubated with $3 \mathrm{E} 8 \mathrm{mAb}$ or goat anti-B7-H4 polyclonal antibody for $30 \mathrm{~min}$ at $4{ }^{\circ} \mathrm{C}$. Normal mouse $\operatorname{IgM}$ was used as an antibody control. Cells were washed and resuspended in a solution of goat antimouse IgM coupled with FITC or donkey anti-goat IgG coupled with FITC. Finally, cells were washed twice and samples were analyzed using a FACScan flow cytometer. 
A

Normal
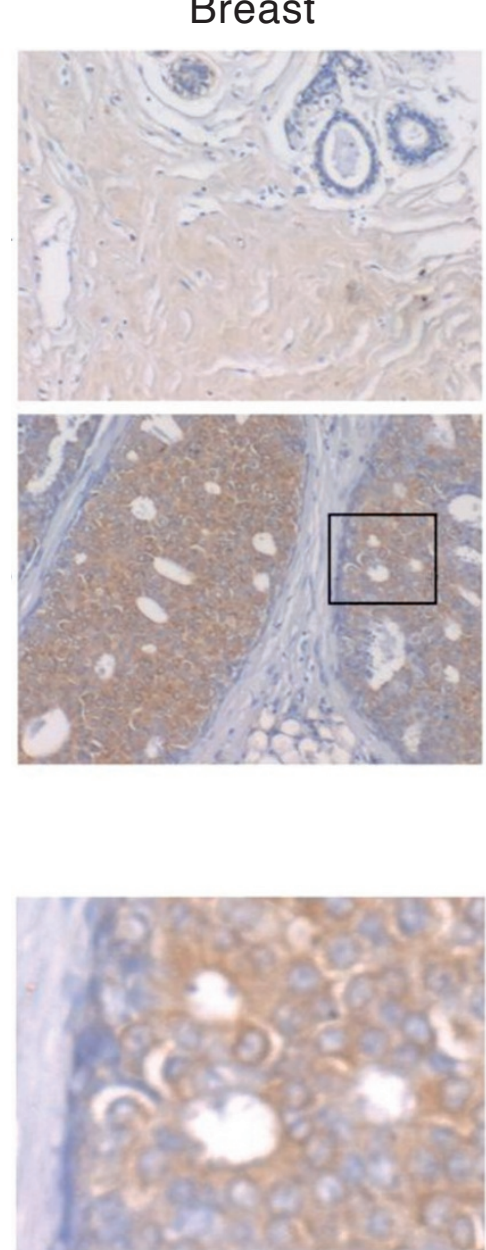

Uterus
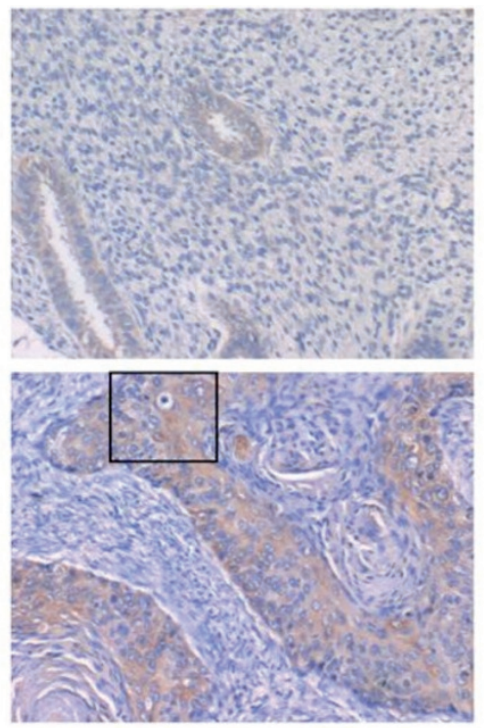

$x 200$

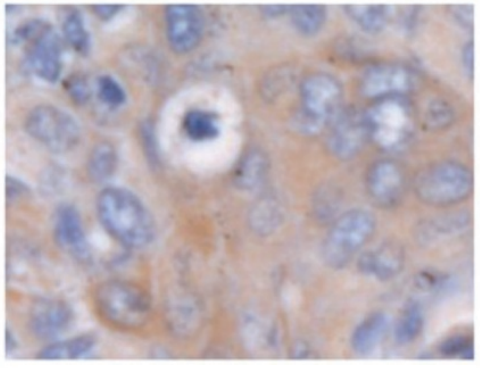

$x 400$
Ovary
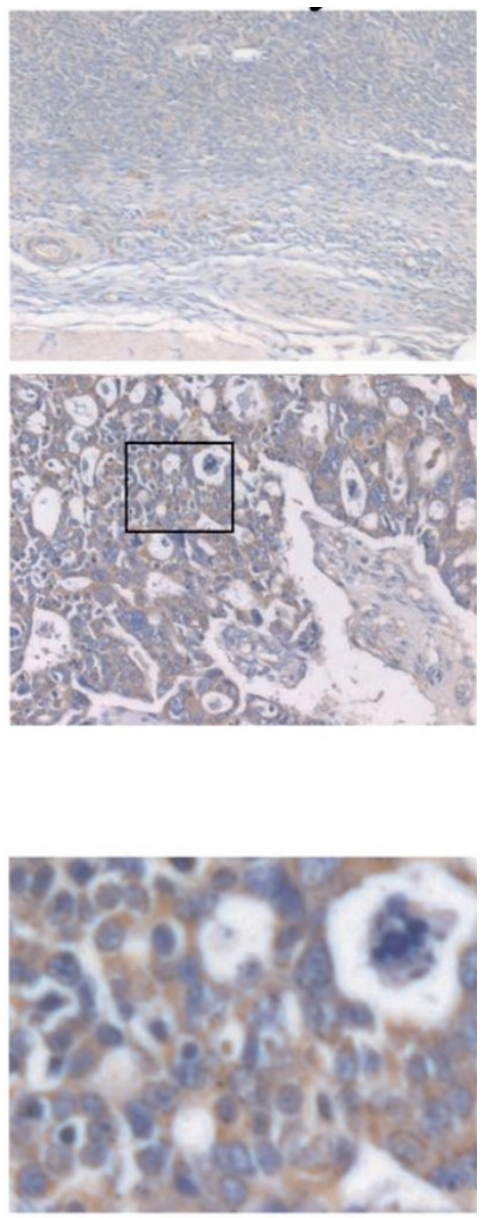

B

Normal

Tumor

\begin{tabular}{lcccccc} 
Tissues & Case No. & No of positive & Total & Case No. & No of positive & Total \\
\hline Breast & 36 & 18 & $1,23 \pm 0.78$ & 43 & 39 & $6.43 \pm 0.32^{* *}$ \\
Uterus & 33 & 19 & $1.68 \pm 0.38$ & 56 & 52 & $6.28 \pm 0.76^{* *}$ \\
Ovary & 35 & 17 & $1.43 \pm 0.34$ & 48 & 45 & $6.53 \pm 0.59^{* *}$ \\
\hline
\end{tabular}

**: vs normal tissue, $\mathrm{P}<0.01$

Fig. 5. Expression of B7-H4 in normal tissues and corresponding cancer samples from breast, uterus, and ovary. - Human normal and cancerous samples in tissue arrays were subjected to IHC staining using mAb 3E8. The reactions were visualized using reagents from a DAKO Envision System kit. Normal mouse IgM was used as an antibody control (data not shown). Samples were photographed and staining intensity ( 0 to 3 , least intense to most intense) and the proportion of stained cells ( 0 to 4 , no cells stained to more than $70 \%$ cells stained) were semi-quantitatively determined. A combined score of $\geq 6$ was considered to indicate overexpression.

\section{Spleen Cell Growth and Cytokines Assays}

B7-H4 can preven T cell proliferation, cytokine secretion [1, 3-4]. In order to test the anti or activation effect of $3 \mathrm{E} 8$ on $\mathrm{B} 7-\mathrm{H} 4$, we analysed the normal mouse spleen cell growth and cytokines secretion while cultured with or without B7-H4 or 3E8 (Fig. 6). The number of living cells and the expression levels of IL-2, IL-4, IL-10, and IFN- $\gamma$ which were cultured with the admixture of $3 \mathrm{E} 8$ and $\mathrm{B} 7-\mathrm{H} 4$ was increased in a $3 \mathrm{E} 8$-concentration-dependent manner compared with living cells cultured with only B7-H4. And there was a significant difference while $3 \mathrm{E} 8$ was 5 $\mathrm{ug} / \mathrm{ml}$.

\section{Discussion}

The structure of B7-H4 as a GPI-linked molecule distinguishes it from other B7 family members. The 90\% amino acid identity between mouse and human B7-H4 


\section{A}
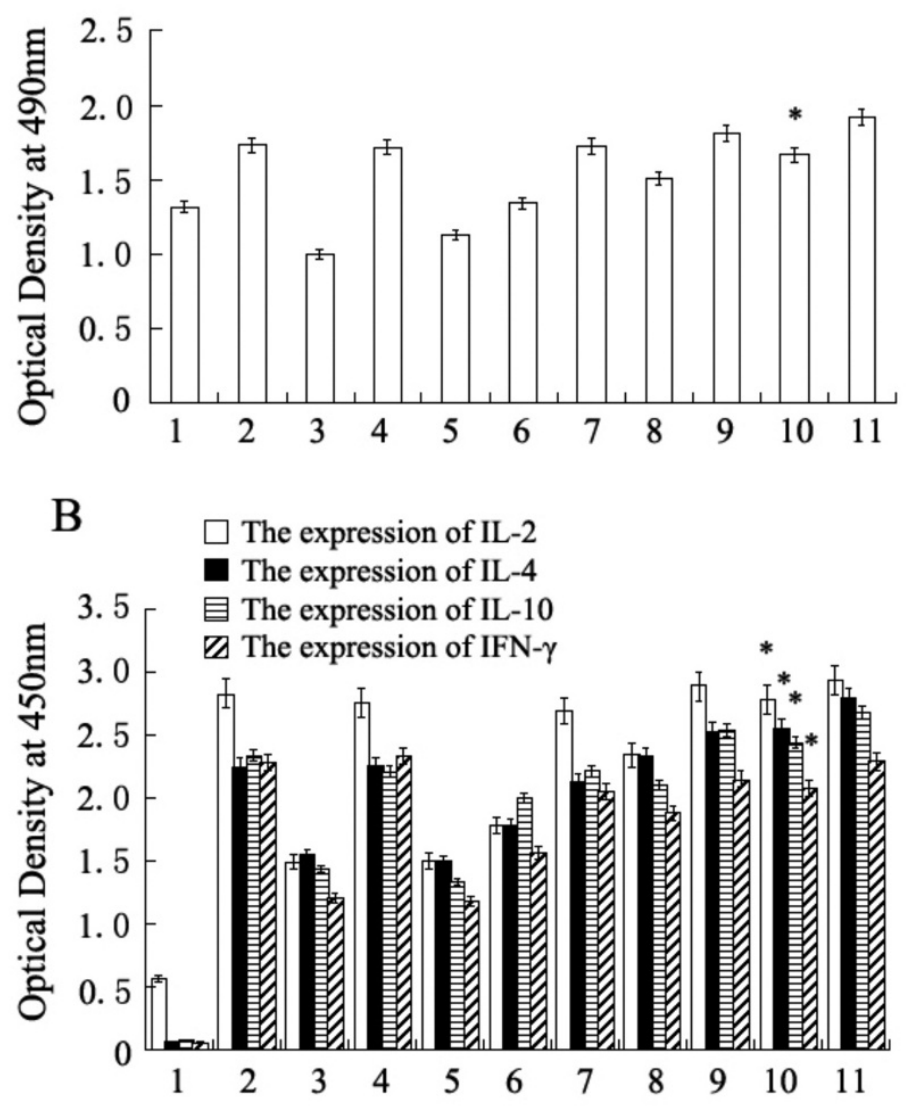

\begin{tabular}{|c|c|c|c|c|c|c|c|c|c|c|c|}
\hline Spleen cells & + & + & + & + & + & + & + & + & + & + & + \\
\hline Anti-CD3 mAb & & + & + & + & + & + & + & + & + & + & + \\
\hline B7-H4(2 ug/ml) & & & + & & + & + & & + & & + & \\
\hline Normal IgM (5 ug/ml) & & & & + & + & & & & & & \\
\hline $3 \mathrm{E} 8(1 \mathrm{ug} / \mathrm{ml})$ & & & & & & + & + & & & & \\
\hline $3 \mathrm{E} 8(2 \mathrm{ug} / \mathrm{ml})$ & & & & & & & & + & + & & \\
\hline $3 \mathrm{E} 8(5 \mathrm{ug} / \mathrm{ml})$ & & & & & & & & & & + & + \\
\hline
\end{tabular}

Fig. 6. Spleen cell growth and cytokines secretion assays. - A: Spleen cell growth determined by MTS. Spleen cells from normal Balb/c mouse $\left(2 \times 10^{5}\right.$ cells per well $)$ were seeded in triplicate in a 96-well plate which was coated with anti-mouse CD3 mAb. Then, the cells were incubated with the purified recombinant $\mathrm{B} 7-\mathrm{H} 4$ protein, $3 \mathrm{E} 8 \mathrm{mAb}$, or their admixture which was premixed for $30 \mathrm{~min}$. Normal mouse IgM was used as an antibody control. After incubating the wells for 72 hours at $37^{\circ} \mathrm{C}$, the wells were added with MTS. After incubating the wells for 4 hours at $37^{\circ} \mathrm{C}$, the OD of each well was measured using a Model 680 microplate reader at a wavelength of $490 \mathrm{~nm}$. The numbers of living cells were presented by OD490. B: Cytokines secretion determined by ELISA. Spleen cells were treated as above. The Cell culture supernatant was collected respectively after incubating the wells for 48 or 72 hours at $37^{\circ} \mathrm{C}$. The expression of IL-2, IL-4, IL-10 in 48h supernatant, and IFN- $\gamma$ in $72 \mathrm{~h}$ supernatant were determined with mouse cytokine ELISA kit. The expression levels of cytokines were presented by OD450. *: vs Lane 3 and Lane $5, \mathrm{P}<0.05$. suggests an important evolutionarily conserved function. Thus, in this study, we established a 3T3-mB7$\mathrm{H} 4$ cell line expressing extrinsic $\mathrm{mB} 7-\mathrm{H} 4$ on the cell membrane, and used this as an immunogen to immunize Balb/c mice in order to obtain $\mathrm{mAbs}$ specific to the human and mouse homologous fragments. The $3 \mathrm{E} 8 \mathrm{mAb}$, an IgM with a $\kappa$ chain, could specifically recognize the extracellular domain of $\mathrm{B} 7-\mathrm{H} 4$ with ELISA, IP, and western blot analysis.

Flow cytometry is a rapid, quantitative, multiparameter cellular analysis based on the measurement of visible and fluorescent light emission. We used 3E8 $\mathrm{mAb}$ for further characterization of $\mathrm{B} 7-\mathrm{H} 4$ based on the strong signals detected by immunofluorescence. Previous studies have shown that expression of B7H4 was detected in some human tumor tissues and cells [15]. We assayed the human lymphoid hematopoietic tumor cell lines for expression of B7-H4 using flow cytometry. The results demonstrated that the $\mathrm{mAb}$ exhibits excellent reactivity when applied to leukemic cells. It indicated that the $3 \mathrm{E} 8 \mathrm{mAb}$ is effective for detecting B7-H4 using flow cytometry, and the positive tendency was consistent with the goat antiB7-H4 polyclonal antibody. It has been reported that $\mathrm{B} 7-\mathrm{H} 4$ is constitutively expressed on some leukemic cells derived from B-cell lymphoma cells [20]. Therefore, aberrant B7-H4 expression may provide a theoretical basis for the clinical detection and diagnosis of leukemia. Many studies have shown that monoclonal antibodies can be used for targeted therapy in clinical disease [21]. Thus, it may be possible to develop 3E8 $\mathrm{mAb}$ as a therapeutic monoclonal antibody for clinical therapy.

It is reported that B7-H4 was overexpressed in tumor tissues from the breast [6], ovary [22], and uterus [23]. In order to test whether the $3 \mathrm{E} 8 \mathrm{mAb}$ could be used in immunohistochemistry, we determined the expression of $\mathrm{B} 7-\mathrm{H} 4$ in tumor tissues from the breast, ovary, and uterus. The levels of B7-H4 expressed in various types of cancer samples were evaluated in a standardized and semi-quantitative manner using the 3 E8 mAb. Samples with scores $\leq 2$ were mostly observed in normal tissue with a predominantly apical membranous staining. Overexpression of B7-H4 (scores $\geq 6.0$ ) was found only in tumor tissues with a predominantly diffuse plasmalemmal or cytoplasmic pattern. These results are consistent with previous studies [5-7, 12-13]. Thus, the 3E8 mAb can detect the expression of B7-H4 using IHC staining. The identification of cancers with high rates of $\mathrm{B} 7-\mathrm{H} 4$ overex- 
pression provides valuable information about the pathogenic potential of B7-H4 in tumor development and malignant progression. The aberrant B7-H4 expression and an $\mathrm{mAb}$ specific to $\mathrm{B} 7-\mathrm{H} 4$ may provide not only a new insight into the mechanisms of tumor occurrence and development but also a new method for the prevention and treatment of tumors [20-21, 24-25].

B7-H4 can inhibit the $\mathrm{T}$ cell proliferation and cytokines secretion such as IL-2, IL-4, IL-10, and IFN- $\gamma$ $[1,3-4]$. The presence of recombinant $\mathrm{B} 7-\mathrm{H} 4$ at $0.5-3$ $\mu \mathrm{g} / \mathrm{mL}$ inhibited the anti-CD3-induced proliferation of $\mathrm{T}$ cells by $40-60 \%$ (details seen the manual of B7$\mathrm{H} 4$ in R\&D system). So the concentration of B7-H4 in spleen cell growth and cytokines secretion assays was $2 \mu \mathrm{g} / \mathrm{mL}$. And B7-H4 could inhibit the anti-CD3induced proliferation and cytokines secretion of spleen cells which were cultured with only B7-H4 (Fig. 6).

Antibodies can specifically bind to its ligand and lead to target cell lysis or blocking the pathological process. So the development of the antibodies in particular humanized antibody drug plays an important role in clinical therapy of human malignant and other autoimmune diseases [26-27]. In this study, 3E $8 \mathrm{mAb}$ can effectively stimulate $\mathrm{T}$ cell proliferation, and induce of IL-2, IL-4, IL-10, and IFN- $\gamma$ production, suggesting that $3 \mathrm{E} 8 \mathrm{mAb}$ can block $\mathrm{B} 7-\mathrm{H} 4$ binding to its receptor, which closed down-regulation signal transduction of B7-H4 to T cell, and enhanced T cell reactivity to various antigens. $3 \mathrm{E} 8 \mathrm{mAb}$ as an inhibitor of $\mathrm{B} 7-\mathrm{H} 4-$ mediated negative regulation of $\mathrm{T}$ cell activation, can activate the immune response. But the mechanism is still being researched. B7-H4 and anti-B7-H4 $\mathrm{mAb}$ as an important factor of $\mathrm{T}$ cell function can play specific therapeutic effects of disease which is high efficacy, through the intervention of immune microenvironment. And thus we can open up a new way of gene therapy. But at the same time, we should also note the potential impact of long-term application, such as B7-H4 mAb over-blocking signal of B7-H4 and its receptor leading to autoimmune diseases.

In summary, we generated specific mAbs directed against $\mathrm{B} 7-\mathrm{H} 4$. The $\mathrm{mAb} 3 \mathrm{E} 8$ exhibited the best performance in a variety of assays, including immunoblotting, IP, flow cytometry, and IHC staining. And the mAb could effectively inhibit the function of $\mathrm{B} 7-\mathrm{H} 4$ in the inhibition of $\mathrm{T}$ cell, while promoting the growth of $\mathrm{T}$ cells and the secretion of IL-2, IL-4, IL-10 and IFN- $\gamma$. This specific $\mathrm{mAb}$ may provide an ideal tool for further investigation of the function of B7-H4.

Acknowledgement: This study was supported by a grant \#30972777 (to HPY) from the National Natural Science Foundation of China.

\section{REFERENCES}

1. Sica GL, Choi IH, Zhu G, Tamada K, Wang SD, Tamura $\mathrm{H}$, Chapoval AI, Flies DB, Bajorath J, Chen L. B7-H4, a molecule of the B7 family, negatively regulates $\mathrm{T}$ cell immunity. Immunity. 2003; 18: 849-861

2. Chen L. Co-inhibitory molecules of the B7- CD28 family in the control of $\mathrm{T}$ cell immunity. Nature Rev Immunol. 2004; 4: 336-347
3. B7x: a widely expressed B7 family member that inhibits $\mathrm{T}$ cell activation. Proc Natl Acad Sci USA. 2003; 100: 10388-10392

4. Prasad DVR, Richards S, Mai XM, Dong C. B7S1, a novel B7 family member that negatively regulates $\mathrm{T}$ cell activation. Immunity. 2003; 18: 863-873

5. Salceda S, Tang T, Kmet M, Munteanu A, Ghosh M, Macina R, Liu W, Pilkington G, Papkoff J. The immunomodulatory protein $\mathrm{B} 7-\mathrm{H} 4$ is overexpressed in breast and ovarian cancers and promotes epithelial cell transformation. Exp Cell Res. 2005; 306: 128-141

6. Tringler B, Zhuo S, Pilkington G, Torkko KC, Singh M, Lucia MS, Heinz DE, Papkoff J, Shroyer KR. B7-h4 is highly expressed in ductal and lobular breast cancer. Clin Cancer Res. 2005; 11: 1842- 1848

7. Choi IH, Zhu G, Sica GL, Strome SE, Cheville JC, Lau JS, Zhu Y, Flies DB, Tamada K, Chen L. Genomic organization and expression analysis of $\mathrm{B} 7-\mathrm{H} 4$, an immune inhibitory molecule of the B7 family. J Immunol. 2003; 171: 4650- 4654

8. Krambeck AE, Thompson RH, Dong H, Lohse CM, Park ES, Kuntz SM, Leibovich BC, Blute ML, Cheville JC, Kwon ED. B7-H4 expression in renal cell carcinoma and tumor vasculature: associations with cancer progression and survival. Proc Nati Acad Sci USA. 2006; 103: 10391- 10396

9. Zang X, Thompson RH, Al-Ahmadie HA, Serio AM, Reuter VE, Eastham JA, Scardino PT, Sharma P, Allison JP. B7-H3 and B7x are highly expressed in human prostate cancer and associated with disease spread and poor outcome. Proc Natl Acad Sci USA. 2007; 104: 19458-19463

10. Sun Y, Wang Y, Zhao J, Gu M, Giscombe R, Lefvert AK, Wang X. B7-H3 and B7-H4 expression in non-small-cell lung cancer. Lung Cancer. 2006; 53: 143- 151

11. Kryczek I, Zou L, Rodriguez P, Zhu G, Wei S, Mottram P, Brumlik M, Cheng P, Curiel T, Myers L, Lackner A, Alvarez X, Ochoa A, Chen L, Zou W. B7-H4 expression identifies a novel suppressive macrophage population in human ovarian carcinoma. J Exp Med. 2006; 203: 871-881

12. Simon I, Zhuo S, Corral L, Diamandis EP, Sarno MJ, Wolfert RL, Kim NW. B7-H4 Is a Novel MembraneBound Protein and a Candidate Serum and Tissue Biomarker for Ovarian Cancer. Cancer Res. 2006; 66: 15701575

13. Thompson RH, Zang X, Lohse CM, Leibovich BC, Slovin SF, Reuter VE, Cheville JC, Blute ML, Russo P, Kwon ED, Allison JP. Serum-soluble B7x is elevated in renal cell carcinoma patients and is associated with advanced stage. Cancer Res. 2008; 68: 6054-6058

14. Mugler KC, Singh M, Tringler B, Torkko KC, Liu W, Papkoff J, Shroyer KR. B7-h4 expression in a range of breast pathology: correlation with tumor T-cell infiltration. Appl Immunohistochem Mol Morphol. 2007; 15(4): 363-370

15. Qian Y, Shen L, Cheng LF, Wu ZG, Yao HP. B7-H4 expression in various tumors determined using a novel developed monoclonal antibody. Clin Exp Med. 2010; [printed in head]

16. Yao HP, Luo YL, Feng L, Cheng LF, Lu Y, Li W, Wang MH. Agonistic monoclonal antibodies potentiate tumorigenic and invasive activities of splicing variant of the RON receptor tyrosine kinase. Cancer Biol Ther. 2006; 5: 1179-1186

17. Nelson PN, Reynolds GM, Waldron EE, Ward E, Giannopoulos K, Murray PG. Monoclonal antibodies. Molecular Pathology. 2000; 53 : 111-117

18. Qian Y, Yao HP, Cheng LF, Shen L, Gu LJ, Tao L, Zhang LH. Expression and identification of recombinant mouse gene B7-H4. Journal of Zhejiang University (medical sciences). 2009; 38: 117-124 
19. Allred DC, Harvey JM, Berardo M, Clark GM. Prognostic and predictive factors in breast cancer by immunohistochemical analysis. Mod Pathol. 1998; 11: 155-168

20. Park GB, Song H, Kim YS, Sung M, Ryu JW, Lee HK, Cho DH, Kim D, Lee WJ, Hur DY. Cell cycle arrest induced by engagement of $\mathrm{B} 7-\mathrm{H} 4$ on Epstein-Barr viruspositive B-cell lymphoma cell lines. Immunology. 2009; 128(3): 360-368

21. Guin S, Yao HP, Wang MH. RON receptor tyrosine kinase as a target for delivery of chemodrugs by antibody directed pathway for cancer cell cytotoxicity. Mol Pharm. 2010; 7(2): 386-397

22. Tringler B, Liu W, Corral L, Torkko KC, Enomoto T, Davidson S, Lucia MS, Heinz DE, Papkoff J, Shroyer KR. B7-H4 overexpression in ovarian tumors. Gynecol Oncol. 2006; 100: 44- 52

23. Miyatake T, Tringler B, Liu W, Liu SH, Papkoff J, Enomoto T, Torkko KC, Dehn DL, Swisher A, Shroyer KR. B7-H4 (DD-O110) is overexpressed in high risk uterine endometrioid adenocarcinomas and inversely correlated with tumor T-cell infiltration. Gynecol Oncol. 2007; 106: 119-127

24. Cheng L, Jiang J, Gao R, Wei S, Nan F, Li S, Kong B. B7$\mathrm{H} 4$ expression promotes tumorigenesis in ovarian cancer. Int J Gynecol Cancer. 2009; 19: 1481-1486

25. Jiang J, Zhu Y, Wu C, Shen Y, Wei W, Chen L, Zheng X, Sun J, Lu B, Zhang X. Tumor expression of B7-H4 predicts poor survival of patients suffering from gastric cancer. Cancer Immunol Immunother. 2010; 59(11): 1707 1714
26. Azzoni C, Bottarelli L, Cecchini S, Lagrasta C, Pizzi S, D'Adda T, Tamburini E, Rindi G, Bordi C. Involvement of HER-2/neu and metastasis-related proteins in the development of ileal neuroendocrine tumors. Virchows Arch. 2011; [Epub ahead of print]

27. Zynek-Litwin M, Kuzniar J, Nocen-Rychlewska B, Kusztal M, Klinger M. An inconspicuous insect bite as the cause of sepsis in a patient treated with infliximab due to rheumatoid arthritis. Adv Med Sci. 2011; [Epub ahead of print]

Received: May 2, 2011 / Accepted: May 16, 2011

Address for correspondence:

Hang-Ping Yao, Associate Professor

State Key Laboratory for Diagnosis and Treatment of Infectious Diseases

The First Affiliated Hospital

Zhejiang University School of Medicine

79 Qingchun Road

Hangzhou 310003

China

Tel: $\quad+86-571-87236580$

Fax: $\quad+86-571-87236582$

E-mail: yaohangping@zju.edu.cn 